\title{
Suppression of concanavalin A-induced responses in splenic lymphocytes by activated macrophages in the non-obese diabetic mouse
}

\author{
K. Yokono, Y. Kawase, M. Nagata, N. Hatamori and S. Baba \\ Second Department of Internal Medicine, Kobe University School of Medicine, Kobe, Japan
}

\begin{abstract}
Summary. Spleen cells from non-obese diabetic mice were found to generate low interleukin 2 production and cell proliferation in response to concanavalin A. However, some of non-obese diabetic mice maintained in the same environment preserved their responsiveness to this $T$ cell mitogen. Nonobese diabetic mice at every age had a higher percentage of Thyl.2, L3T4, and Lyt2-positive spleen cells than did control mice, suggesting that the dysfunction of spleen cells did not depend on the number of $T$ cells or the ratio of these subpopulations. Evidence for macrophage-mediated suppression participating in the deficient function of splenic lymphocytes in this mouse model of insulin-dependent diabetes includes: 1) the restoration of mitogen-induced interleukin 2 production after the macrophages have been depleted by silica absorption form spleen cells;2) the complete suppression of the cell proliferation by thioglycollate-stimulated peritoneal exudate cells
\end{abstract}

from non-obese diabetic and control mice, and the partial suppression by spleen macrophages from non-obese diabetic mice; 3) the reversal of the suppression of interleukin 2 production by the prostaglandin synthetase inhibitor indomethacin $(0.1-1 \mu \mathrm{g} / \mathrm{ml}) ; 4)$ the partial suppression of interleukin 2 production, conversely, by the exogenous prostaglandins $\mathrm{E}_{1}$ and $E_{2}\left(2.5 \times 10^{-6} \mathrm{~mol} / \mathrm{ll}\right)$. These results indicate that the activated macrophages existing among the spleen cells suppress the response of splenic $T$ cells to concanavalin $A$. This impairment may contribute to the pathogenesis of insulin-dependent diabetes in non-obese diabetic mice.

Key words: Type 1 (insulin-dependent) diabetes, non-obese diabetic mouse, $T$ cells, macrophages, concanavalin $A$, interleukin 2.
Recently, it has become generally accepted that $\mathrm{T}$ cellmediated autoimmunity contributes to the pathogenesis of insulin-dependent diabetes in humans and animals. Evidence in human Type 1 (insulin-dependent) diabetic patients includes abnormalities of $\mathrm{T}$ cell subsets $[1,2]$, the increase of Ia-positive activated T cells [3, 4], and the preponderance of $T$ cells in the mononuclear cell infiltration into islets (insulitis) [5]. In the BB Wistar rat, a model of human Type 1 diabetes, diabetes can be transferred by concanavalin A (Con A)-stimulated spleen cells obtained from acute diabetic rats [6]. The disease can be prevented by neonatal thymectomy [7], cyclosporin A treatment [8], or transfusion of peripheral blood $\mathrm{T}$ cells from non-diabetes-prone animals into diabetes-prone recipients [9]. Furthermore, in the nonobese diabetic (NOD) mouse, another suitable model for human Type 1 diabetes, neonatal thymectomy [10], administration of anti-thymocyte serum [11], or the transfer of the nude gene [12] has prevented insulitis and development of diabetes. In two recent studies, most of the islet-infiltrating cells in the NOD mouse were deter- mined to be $\mathrm{T}$ cells by electron microscopic examination [13] and flow cytometric analysis [14].

In parallel with these studies, there are many reports currently available concerning the analysis of $T$ cell function in Type 1 diabetes using interleukin 2 (IL-2) production and cell proliferation. IL-2 production by peripheral lymphocytes was reduced in patients with Type 1 diabetes $[15,16]$. This defect is not correlated with an ongoing autoimmune process or with poor metabolic control, suggesting that the defect might be involved in the pathogenesis of the disease. Spleen cells from diabetes-prone BB Wistar rats generated low IL-2 production and proliferative responses in response to a T cell mitogen [17-19]. It has been suggested that macrophages act as suppressor elements in the low responsiveness of BB rat $T$ cells to mitogen $[18,19]$. The production of IL-2 by NOD spleen cells in response to Con A was also much lower than that of control mice. However, no relation was confirmed between excessive macrophage suppression and the low production of IL2 in the NOD mouse [20]. 
In any case, these findings strongly suggest that $\mathrm{T}$ cell-mediated immunity plays an important role in the autoimmune phenomenon in Type 1 diabetes. In the present study, we have examined first the changes among the sub-populations of splenic T cells as a function of age in NOD mice. Secondly, we have measured the responsiveness of NOD spleen cells to Con A using IL-2 production and cell proliferation. Finally, the effect of macrophages on these responses has been also examined.

\section{Materials and methods}

\section{Animals}

NOD mcie were kindly supplied by Aburahi Laboratories, Shionogi Research Institute (Shiga, Japan) and bred at the Experimental Animal Centre, Kobe University School of Medicine, in a specific pathogen-free state. In our colony, mononuclear cell infiltration of islets (insulitis) begins around 5-6 weeks of age, overt diabetes occurs mainly at 15 weeks after birth and the cumulative incidence of diabetes at 30 weeks of age is $70-75 \%$ for female NOD mice. Since NOD mice were derived originally from Institute of Cancer Research (ICR) mice [21], female ICR mice served as a control and were purchased from Clea (Osaka, Japan). Furthermore, female BALB/c mice were also used as a control and purchased from Clea.

\section{Flow cytometric analysis}

Spleens were obtained from female NOD and ICR mice aged 3-30 weeks and BALB/c mice aged 13 weeks. Spleen cell suspensions were prepared by teasing apart spleens in Hank's balanced salt solution (HBSS). After haemolysis with $15 \mathrm{mmol} / \mathrm{ml}$ Tris- $0.83 \% \mathrm{NH}_{4} \mathrm{Cl}$ ( $\mathrm{pH} 7.4$ ), the spleen cells were washed 3 times with HBSS and resuspended in Dalbecco's phosphate-buffered saline containing 1\% fetal calf serum (Gibco, Grand Island, NY, USA) and $0.1 \%$ sodium azide. The cell surface staining was carried out by incubation with fluorescein isothiocyanate (FITC)-conjugated monoclonal anti-Thyl. 2 and Lyt2 antibodies, and phycoerythrin (PE)-conjugated monoclonal anti-L3T4 antibody (Becton Dickinson, Monoclonal Center, Moutain View, Calif, USA) for $30 \mathrm{~min}$ at $4^{\circ} \mathrm{C}$ using $4 \mu \mathrm{l}$ of antibody per $10^{6}$ cells. Samples were analysed on a FACS 440 flow cytometry (Becton Dickinson).

\section{IL-2 production and cell proliferation after mitogen stimulation}

Spleen cells isolated from NOD, ICR and BALB/c mice at 13 weeks of age were resuspended in RPMI-1640 medium supplemented by $10 \%$ fetal calf serum, glutamine $(1 \mathrm{mmol} / 1)$, sodium pyruvate $(2 \mathrm{mmol} / 1)$, penicillin $(50 \mathrm{U} / \mathrm{ml})$, streptomycin $(50 \mu \mathrm{g} / \mathrm{ml})$, and 2 mercaptoethanol $(50 \mu \mathrm{mol} / \mathrm{l})$. These cells were co-cultured at $1 \times 10^{5}$ cells/well with $0.005-50 \mu \mathrm{g} / \mathrm{ml}$ Con A in $0.2 \mathrm{ml}$ in 96 -well microtitre culture plates. After a $24 \mathrm{~h}$ incubation, each supernatant $(100 \mu \mathrm{l})$ was collected and measured for IL-2 content. The IL-2 assay was performed as described by Gillis et al. [22] using the IL-2-dependent CTLL-2 cell line. Briefly, CTLL-2 cells $\left(1 \times 10^{4} /\right.$ well $)$ were cultured with supernatants and ${ }^{3} \mathrm{H}$-thymidine uptake was measured after $20 \mathrm{~h}$ of culture, following a $4 \mathrm{~h}$ incubation with $1 \mu \mathrm{Ci}^{3} \mathrm{H}$-thymidine (specific activity: $20-30 \mathrm{Ci} / \mathrm{mmol}$, Amersham Japan, Tokyo, Japan) per well. The cultures were harvested on fiberglass filters by a multiharvester and incorporation of thymidine was measured in a liquid scin- tilation counter. For cell proliferation, ${ }^{3} \mathrm{H}$-thymidine uptake was measured after $72 \mathrm{~h}$ of culture, following a $18 \mathrm{~h}$ incubation with ${ }^{3} \mathrm{H}$ thymidine,

\section{Effect of macrophage depletion from spleen cells by silica absorption on IL-2 production}

Spleen cells $\left(5 \times 10^{6} / \mathrm{ml}\right)$ obtained from mice at 13 weeks of age were resuspended in $100 \mu 1$ of $5 \%$ silica gel in phosphate-buffered saline (PBS, pH 7.4) (KAC2, silica size; 5 micron, Japan Antibody Research Lab., Takasaki, Japan) and $0.5 \mathrm{ml}$ of mouse serum. After incubation for $1 \mathrm{~h}$ at $37^{\circ}$, splenic lymphocytes were isolated by Ficoll-Hypaque gradient centrifugation. The cells were washed 3 times with RPMImedium, viable cells were counted, and aliquots were evaluated as macrophage-depleted cells with flow cytometry using a monoclonal anitbody to Mac-1 antigen (Hybritech Inc., San Diego, Calif, USA) which recognises an antigen generally present on splenic and peritoneal macrophages [23]. Although Mac-1-positive cells usually comprise 5-10\% of the spleen cells of NOD mice, the cells were completely depleted after treatment with silica. Spleen cells either depleted of Mac- $1^{+}$cells or not $\left(2 \times 10^{5}\right)$ were cultured with or without $5 \mu \mathrm{g} / \mathrm{ml}$ Con A, and their IL-2 production was measured as described above.

\section{Effect of peritoneal exudate cells on cell proliferation of macrophage-depleted spleen cells}

NOD and BALB/c mice aged 13 weeks were received intraperitoneal injection of either $2 \mathrm{ml}$ of $2.5 \%$ thioglycollate (Difco, Detroit, Mich, USA) or PBS. Peritoneal exudate cells (PEC) were obtained 4 days after injection by washing the peritoneal cavity with $5 \mathrm{ml}$ of RPMI medium. The ratio of macrophages in thioglycollate-induced PEC or unstimulated PEC was examined with flow cytometry using a monoclonal antibody to Mac-1. In both strains of mice, PEC from untreated mice contained 15-20\% Mac-1 positive cells; whereas the proportion of Mac-1 positive cells increased in PEC after stimulation with thioglycollate and was consistently more than $65 \%$. Spleen cells from NOD and BALB/c mice aged 13 weeks were treated with silica solution as described above. These macrophage-depleted spleen cells $\left(1 \times 10^{5}\right)$ and either non-stimulated or thioglycollate-stimulated PEC $\left(1-4 \times 10^{4}\right)$ were cultured together with $5 \mu \mathrm{g} / \mathrm{ml}$ of Con A. Cell proliferation was measured after $72 \mathrm{~h}$ of culture as described above.

\section{Effect of spleen macrophages on cell proliferation of macrophage-depleted spleen cells}

Spleen cells from NOD and BALB/c mice aged 13 weeks were added to the wells of 96 -well plates and incubated at $37^{\circ} \mathrm{C}$ for $2 \mathrm{~h}$. Non-adherent cells were recoverd by vigorous flushing with RPMI-1640 medium using a pasteur pipette and viable cells were counted. These macrophage-depleted spleen cells $\left(1 \times 10^{5}\right)$ were added to either new wells or previous wells which were adhered by spleen macrophages. The proliferation of cells in these conditions by Con A was measured as described above.

\section{Effect of indomethacin and prostaglandins on $I L-2$ production}

Indomethacin (0.1-10 $\mu \mathrm{g} / \mathrm{ml}$, Sumitomo Pharma Co., Tokyo, Japan), a potent inhibitor of prostaglandin production, was added to cultures containing $1 \times 10^{5}$ spleen cells from NOD, ICR or BALB $/ \mathrm{c}$ mice aged 10-15 weeks stimulated with $5 \mu \mathrm{g} / \mathrm{ml}$ of Con A. Prostaglandins $E_{1}$ or $\mathrm{E}_{2}\left(2.5 \times 10^{-10}-2.5 \times 10^{-6} \mathrm{~mol} / \mathrm{l}\right.$, Ono Pharma Co., Tokyo, Japan $)$ 


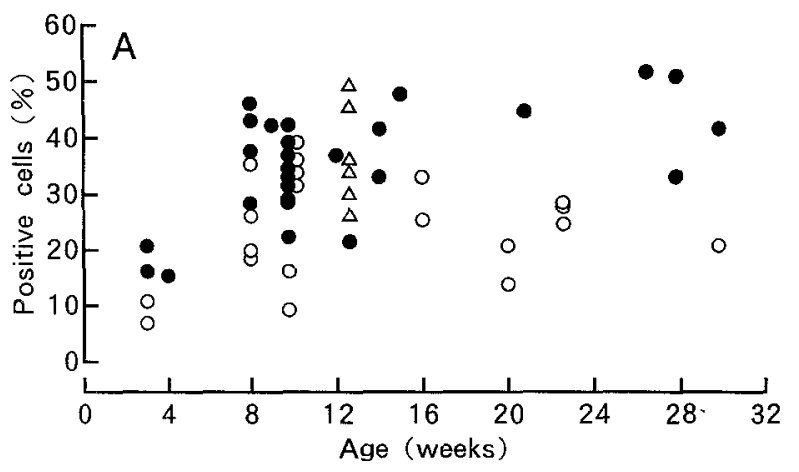

B

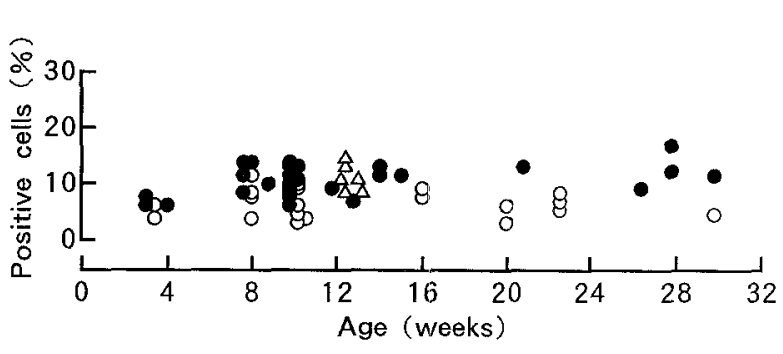

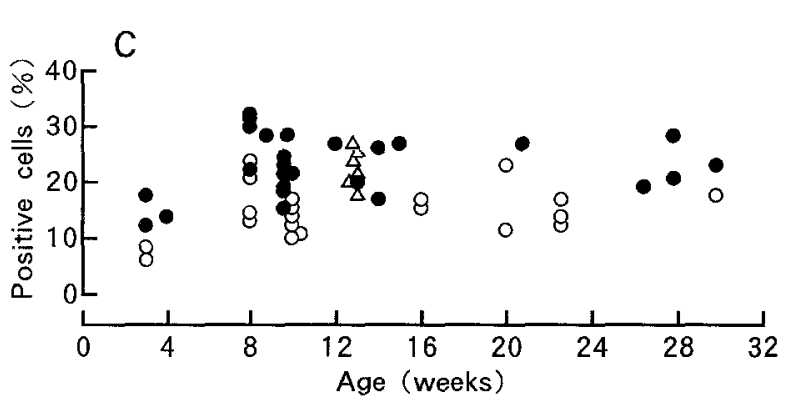

Fig. 1. Percentage of fluorescence-positive cells of spleen cells from non-obese diabetic (NOD) (O) and Institute of Cancer Research $(\mathrm{ICR})(\mathrm{O})$ mice from 3 to 30 weeks of age and from BALB/c mice $(\triangle)$ aged 13 weeks. The cell surface staining was carried out by incubation with fluorescein isothiocyanate-conjugated monoclonal anti-Thyl. 2 (A) and Lyt2 antibodies (B) or phycoerythrin-conjugated monoclonal anti-L3T4 antibody (C) and then analysed by flow cytometry. The percentage of positive cells were estimated by analysis of $10^{4}$ cells. (D) shows the ratio of $\mathrm{L} 3 \mathrm{~T} 4^{+} / \mathrm{Lyt}^{+}{ }^{+}$cells

was added to cultures containing $1 \times 10^{5}$ macrophage-depleted spleen cells from NOD or BALB/c mice aged 10-15 weeks by silica absorption stimulated with $5 \mu \mathrm{g} / \mathrm{ml}$ of Con A. After incubation for $20 \mathrm{~h}$, IL2 production in the culture supernatant was measured as described above.

\section{Statistical analysis}

Results are given as mean $\pm S D$, and statistical evaluation of the data was made by Student's paired $t$-test. A $p$ value of $<0.05$ was considered statistically significant.

\section{Results}

\section{Analysis of splenic lymphocyte subpopulations by flow cytometry}

The age-related changes of lymphocyte sub-populations in spleen cells were examined in NOD and ICR mice from 3 to 30 weeks of age. The cell surface phenotypes of lymphocytes, expressed as the percentage of cells reacting with a given monoclonal antibody, are shown in Figure 1. NOD mice showed slightly higher proportions of Thyl. 2 (pan T cells), L3T4 (helper/inducer T cells), and Lyt2 (suppressor/cytotoxic T cells) positive cells at

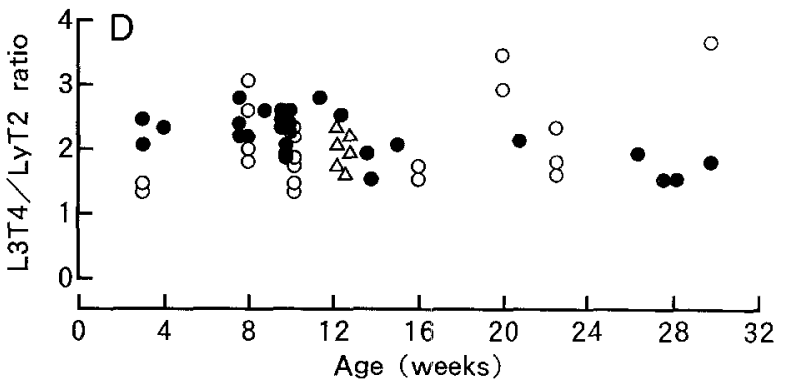

every age examined than did control ICR mice; whereas the ratio of $\mathrm{L} 3 \mathrm{~T} 4^{+} / \mathrm{Lyt}^{+}$cells was not different between NOD and ICR mice. The percentages of positive cells in BALB/c mice aged 13 weeks were slightly higher than ICR mice but approximately the same as NOD mice aged around 13 weeks. The total number of spleen cells were slightly decreased in NOD mice; however, absolute counts of Thyl.2, L3T4, and Lyt2 positive cells were not significantly different among three strains of mice (data not shown).

\section{Response of NOD spleen cells to Con A}

After culture of spleen cells from NOD, ICR, and $\mathrm{BALB} / \mathrm{c}$ mice at 13 weeks of age with $0.005-50 \mu \mathrm{g} / \mathrm{ml}$ of Con A, the IL-2 production of $24 \mathrm{~h}$ Con A supernatants and the proliferative responses of cells after $72 \mathrm{~h}$ culture were measured and depicted in Figure 2. Apparent IL-2 production (Fig. 2A) and cell proliferation (Fig. 2B) were observed in control ICR and BALB/c mice, and maximum responses were shown at 5 and $0.5 \mu \mathrm{g} / \mathrm{ml}$ of Con A concentration, respectively. On the contrary, there was a heterogeneity among NOD mice in the mitogen responsiveness. Both responses of spleen cells from some of NOD mice were very low at every concentration of Con A (NOD low responder), while some of NOD mice demonstrated a response of Con A approximately same as that of control mice (NOD normal responder).

\section{IL-2 production of macrophage-depleted spleen cells}

Selective depletion of macrophages from NOD, ICR, or $\mathrm{BALB} / \mathrm{c}$ mice at 13 weeks of age was accomplished 

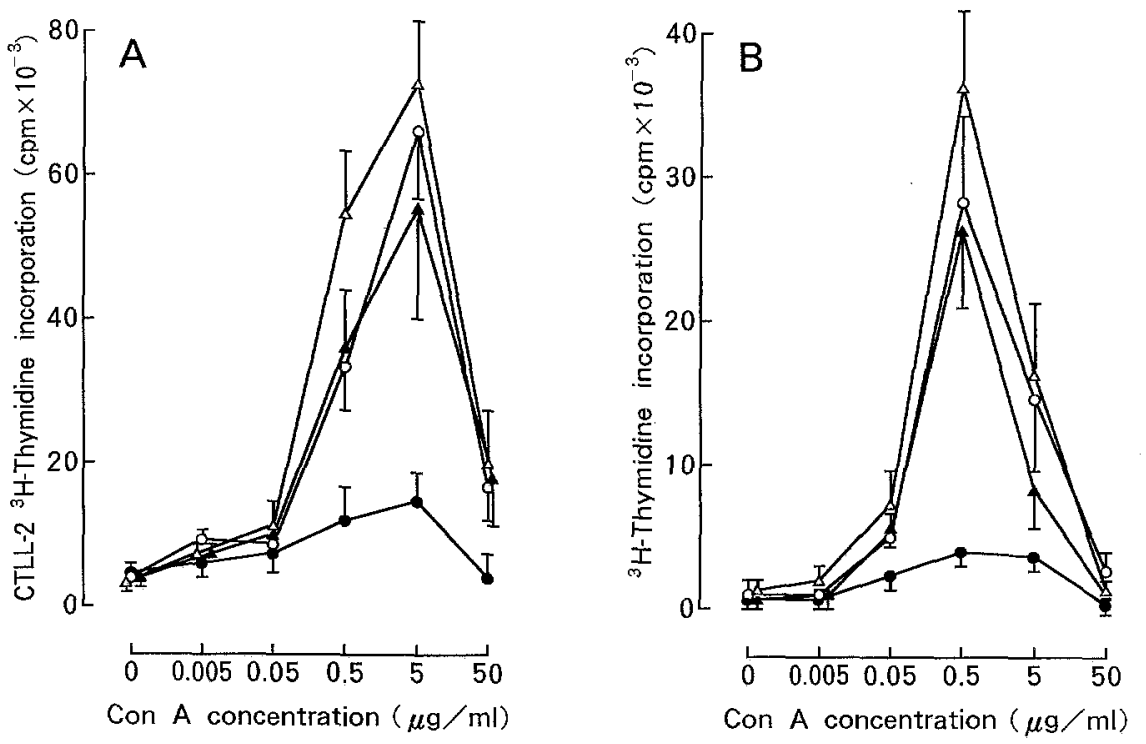

Fig. 2. Effects of Con A concentration on IL-2 production (A) and cell proliferation (B) in spleen cells from NOD, ICR, and BALB/c mice at 13 weeks of age. Stimulation of spleen cells from NOD, ICR $(O)$, and BALB/c $(\triangle)$ mice with $0.005-50 \mu \mathrm{g} / \mathrm{ml}$ concentration of Con A were carried out at $1 \times 10^{5}$ cell density. Since there were two sub-populations among NOD mice in the Con A responsiveness, they were divided into two groups and termed as NOD low responders $(\Theta)$ and normal responders (A), respectively. Results represent the mean \pm SD of six animals

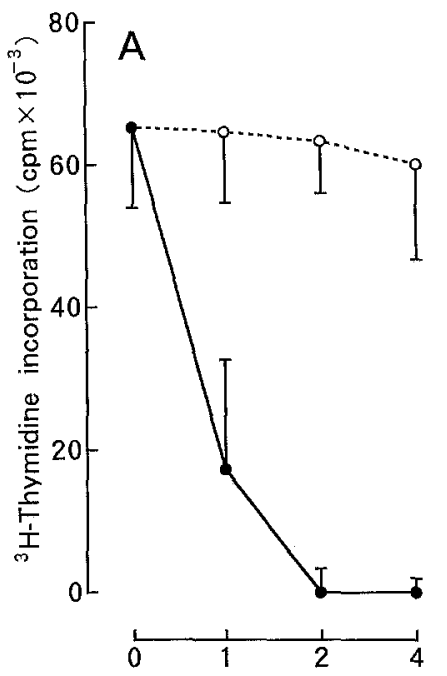

Peritoneal exudate cells $\left(10^{4}\right)$

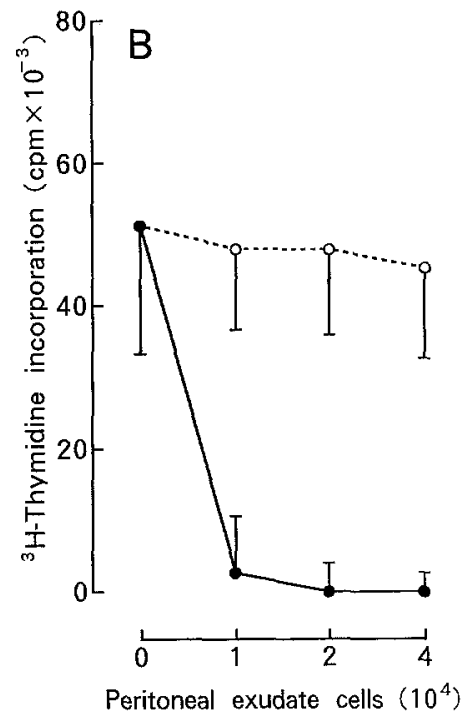

Fig.3. Suppression of cell proliferation of macrophage-depleted spleen cells from BALB/c (A) and NOD (B) mice by thioglycollate-stimulated PEC. Macrophage-depleted spleen cells $\left(1 \times 10^{5}\right)$ from BALB/c or NOD mice aged 13 weeks were cultured with $5 \mu \mathrm{g} / \mathrm{ml}$ Con $A$ in the presence $\left(1-4 \times 10^{4}\right)$ or absence of either non-stimulated $(\mathrm{O}-\mathrm{O}-\mathrm{O})$ or stimulated PEC (-) obtained from each mouse aged 13 weeks. Results represent the mean \pm SD of three animals
Table 1. Effect of macrophage depletion on Con A-induced IL-2 production

\begin{tabular}{llll}
\hline $\begin{array}{l}\text { Mouse } \\
\text { strain }\end{array}$ & $n$ & \multicolumn{2}{l}{$\begin{array}{l}\text { IL-2 production }\left(\mathrm{cpm} \times 10^{-3}\right) \\
\text { Macrophage depletion }\end{array}$} \\
\cline { 2 - 4 } & & Before & After \\
\hline ICR & 5 & $71.4 \pm 12.7$ & $62.9 \pm 9.3$ \\
BALB/c & 5 & $74.8 \pm 9.5$ & $68.3 \pm 8.9$ \\
NOD normal responder & 5 & $57.6 \pm 19.8$ & $63.1 \pm 12.4$ \\
NOD low responder & 5 & $18.5 \pm 3.4^{\mathrm{a}}$ & $65.4 \pm 10.1^{\mathrm{b}}$ \\
\hline
\end{tabular}

Results represent the mean $\pm \mathrm{SD}$. ${ }^{\mathrm{a}} p<0.01$ vs Institute of Cancer Research (ICR), BALB/c and non-obese diabetic (NOD) normal responder before depletion of macrophages. ${ }^{b} p<0.01$ vs NOD low responder before depletion of macrophages. $n=$ number of animals studied

completely by silica absorption; splenic lymphocytes were recovered by Ficoll-Hypaque methods. Table 1 compares the IL-2 production of spleen cells in response to $5 \mu \mathrm{g} / \mathrm{ml} \mathrm{Con} \mathrm{A} \mathrm{before} \mathrm{and} \mathrm{after} \mathrm{depletion} \mathrm{of}$ macrophages. No obvious changes of IL-2 production in response to Con A were seen in ICR and BALB/c mice. Among NOD mice, there are two sub-populations even in this study. NOD mice exhibiting normal responses to Con $\mathrm{A}$ (normal responder) showed a slight increase of IL-2 production after depletion of macrophages. On the other hand, although IL-2 production of some of NOD mice was remarkably low (low responder), macrophage depletion greatly increased IL-2 production, which recovered to approximately the same level achieved by the control mice.

\section{Suppression of cell proliferation of macrophage-depleted spleen cells by peritoneal exudate cells and spleen macrophages}

That macrophages were indeed the suppressor cell population was further demonstrated by adding thioglycollate-induced PEC to macrophage-depleted spleen cells from NOD mice. However, as shown in 
Table 2. Effect of spleen macrophages on cell proliferation of macrophage-depleted spleen cells

\begin{tabular}{|c|c|c|c|}
\hline \multirow{2}{*}{$\begin{array}{l}\text { Mouse } \\
\text { strain }\end{array}$} & \multirow[t]{2}{*}{$n$} & \multicolumn{2}{|c|}{ Cell proliferation $\left(\mathrm{cpm} \times 10^{-3}\right)$} \\
\hline & & $\begin{array}{l}\text { Macrophage } \\
\text { depletion }\end{array}$ & $\begin{array}{l}\text { Macrophage } \\
\text { readmixture }\end{array}$ \\
\hline $\mathrm{BALB} / \mathrm{c}$ & 4 & $64.3 \pm 9.8$ & $60.4 \pm 17.2$ \\
\hline NOD & 4 & $51.2 \pm 18.5$ & $32.5 \pm 14.1$ \\
\hline
\end{tabular}

Results represent the mean \pm SD. $n=$ number of animals studied

Table 3. Effect of indomethacin on Con A-induced IL-2 production

\begin{tabular}{lllll}
\hline $\begin{array}{l}\text { Indometh- } \\
\text { acin } \\
(\mu \mathrm{g} / \mathrm{ml})\end{array}$ & \multicolumn{3}{l}{ IL-2 production $\left(\mathrm{cpm} \times 10^{-3}\right)$} & \\
\cline { 2 - 5 } & ICR (4) & BALB $/ \mathrm{c}(4)$ & NOD & \\
\cline { 3 - 5 } & & & normal (4) & low (4) \\
\hline 0 & $69.1 \pm 15.2$ & $63.5 \pm 14.3$ & $57.2 \pm 14.8$ & $28.6 \pm 7.4^{\mathrm{a}}$ \\
0.1 & $62.3 \pm 4.4$ & - & - & $47.3 \pm 13.5$ \\
1 & $63.8 \pm 2.9$ & - & - & $60.1 \pm 14.0^{\mathrm{b}}$ \\
10 & $65.7 \pm 10.4$ & $59.2 \pm 12.7$ & $58.5 \pm 19.2$ & $60.8 \pm 11.3^{\mathrm{b}}$ \\
\hline
\end{tabular}

Results represent the mean $\pm \mathrm{SD}$. a $p<0.05$ vs ICR, BALB/c, and NOD normal responder without indomethacin; ${ }^{b} p<0.01$ vs NOD low responder without indomethacin. The number of parenthesis indicates the number of animals in each experimental group

Table 4. Effect of prostaglandins on Con A-induced IL-2 production

\begin{tabular}{llll}
\hline Prostaglandin & $\begin{array}{l}\text { Concentration } \\
(\mathrm{mol} / \mathrm{l})\end{array}$ & \multicolumn{2}{l}{ IL-2 production $\left(\mathrm{cpm} \times 10^{-3}\right)$} \\
\cline { 3 - 4 } & & BALB/c & NOD \\
\hline Prostaglandin $\mathrm{E}_{1}$ & 0 & 67.9 & 53.8 \\
& $2.5 \times 10^{-10}$ & - & 54.1 \\
& $2.5 \times 10^{-8}$ & - & 31.7 \\
& $2.5 \times 10^{-6}$ & 48.1 & 30.5 \\
Prostaglandin $\mathrm{E}_{2}$ & 0 & 62.4 & 52.0 \\
& $2.5 \times 10^{-10}$ & - & 50.8 \\
& $2.5 \times 10^{-8}$ & - & 47.4 \\
& $2.5 \times 10^{-6}$ & 44.5 & 39.6 \\
\hline
\end{tabular}

A representative experiment from the three performed is shown

Figure 3 , the addition of $2 \times 10^{4}$ thioglycollate-stimulated PEC from not only NOD (Fig. 3 B), but also BALB/c (Fig. 3 A) mice per culture caused a total suppression of ${ }^{3} \mathrm{H}$-thymidine incorporation by their spleen cells. In contrast, $1-4 \times 10^{4}$ resting normal PEC only slightly inhibited the proliferation of $1 \times 10^{5}$ spleen cells. Since artificially stimulated peritoneal macrophages from both strains of mice strongly suppressed the cell proliferation of splenic lymphocytes, we have next examined the effect of spleen macrophages on cell proliferation of macrophage-depleted spleen cells. Spleen macrophages could not suppress the cell proliferation of splenic lymphocytes in BALB/c mice, whereas cell proliferation of NOD splenic lymphocytes was not significantly but considerably suppressed when they were readmixed with NOD spleen macrophages (Table 2).

\section{Effects of indomethacin and prostaglandins on $I L-2$ production}

Indomethacin, a potent inhibitor of prostaglandin production, was tested for its effect on $\mathrm{IL}-2$ production of NOD, ICR, and BALB/c spleen cells stimulated by Con A (Table 3). Although IL-2 production by spleen cells from NOD low responders was significantly suppressed when compared with that from ICR, BALB/c, and NOD normal responders, the partially suppressed response was protected by indomethacin and the maximal effect was observed with a concentration of $1 \mu \mathrm{g} / \mathrm{ml}$. Finally, we added graded doses of prostaglandins to a culture of Con A-stimulated macrophage-depleted spleen cells from NOD and BALB/c mice and examined their production of IL-2 (Table 4). Prostaglandins $E_{1}$ and $E_{2}$ could suppress IL-2 production in both NOD and BALB/c mice; however, both prostaglandins at concentrations of $2.5 \times 10^{-6} \mathrm{~mol} / 1$ only partially suppressed the IL-2 production of Con A-stimulated spleen cells.

\section{Discussion}

Recently, in order to clarify the pathological participation of T cells in Type 1 diabetes, many analyses of $T$ cell function have used peripheral lymphocytes from human Type 1 diabetic patients and splenic lymphocytes from animal models, in addition to analysing T cell subpopulations. Several have reported that lymphocytes from Type 1 diabetic patients synthesize lower levels of IL-2 than do lymphocytes from non-diabetic control subjects or non-insulin-dependent diabetic patients. Since the abnormality does not appear to result from poor metabolic control or the administration of exogenous insulin, it is thought that the IL-2 deficiency plays a role in disease onset. In the $\mathrm{BB} / \mathrm{W}$ rat, spleen cells from diabetes-prone rats markedly suppressed Con A responses compared with those from nondiabetes-prone $\mathrm{W}$ line rats. Although there was a report that IL-2 production of NOD spleen cells was also remarkably depressed [20], other reports demonstrated that NOD spleen cells had normal responses to Con A $[24,25]$. The present study indicates that spleen cells from some of NOD mice were relatively unresponsive to Con A. However, there were NOD mice demonstrating responses to Con $\mathrm{A}$ approximately equivalent to those of control mice. Thus, we found two sub-populations which were termed as normal and low responders within our colony. The heterogeneity between individual NOD mice was observed not only in the inter-experiment but also in the intra-experiment. The percentage of NOD normal responders was usually $30-50 \%$ in every experiments. The number and the ratio of subpopulations of splenic lymphocytes from each NOD mouse were almost constant (Fig. 1), and neither the age of the mouse nor the concentration of Con A used 
could explain this phenomenon (data not shown). The incidence of diabetes could not be an index for understanding this heterogeneity, because we mainly used NOD mice aged 13 weeks in which overt diabetes do not begin. The histological examination at this age could not find any difference of frequency and severity of insulitis between two sub-populations (data not shown). Since it was impossible to determine whether each NOD mouse exhibits normal or low mitogen responsiveness, we conducted the experiment repeatedly until the number of normal and low responders in each experiment was obtained. The environment maintained in our NOD colony may be able to explain this heterogeneity, because environmental factors may affect the diabetes incidence in this animal model [25]. However, our NOD colony has been maintained constantly in the specific-pathogen-free environment. Thus, it is currently uncertain what causes the heterogeneity in Con A response among individual NOD mice. In the BB rat, activated macrophages act as suppressor elements, causing the low responsiveness of spleen cells to $\mathrm{T}$ cell mitogen. Thus, suppressor macrophages are abnormally plentiful in the spleens of BB rats, but while present, are much rarer in the spleens of control rats [18]. If the low responsiveness of NOD spleen cells to Con A could be caused by suppressor macrophages as reported in $\mathrm{BB}$ rats, the cause for the heterogeneity in the response to Con A might be due to the number of suppressor macrophages in the NOD mouse spleen.

Evidence that suppressor macrophages mediate the low IL-2 production and low proliferative response of NOD spleen cells in response to Con A is as follows: (1) Macrophage depletion by silica absorption from spleen cells of NOD low responders greatly enhanced the response of NOD splenic lymphocytes to Con A; (2) Macrophage-mediated suppression seems to be induced by activated macrophages through the production and secretion of prostaglandins and superoxide radicals [26]. In the present study, the addition of the prostaglandin synthetase inhibitor indomethacin to cultures of NOD spleen cells and Con A resulted in the restoration of responsiveness to this $\mathrm{T}$ cell mitogen. Conversely, the addition of prostaglandins to cultures of NOD macrophage-depleted spleen cells could partly suppress IL-2 production; (3) The addition of thioglycollate-induced PEC which contained many Mac-1positive cells to culture completely suppressed lymphocyte proliferation when compared with the addition of non-stimulated PEC. This complete suppression was observed in BALB/c mice as well as in NOD mice. Because the inhibitory effect of thioglycollate-induced PEC on Con A responses was very prominent, while prostaglandins could only induce a partial suppression, the mechanism of suppression by activated macrophages may be due not only to prostaglandins but also to other compounds produced and released by the activated macrophages, such as oxygen-derived radicals [26] and soluble protein mediators [27]; (4) By readmix- ture of spleen macrophages with macrophage-depleted spleen cells, cell proliferation in NOD mice was considerably suppressed, however, that in BALB/c mice was not. Although it is difficult to estimate the exact number of plastic-adherent cells, these results also suggest that the number of suppressor macrophages in the NOD mouse spleen is fairly greater than in the BALB/c mouse.

Although macrophages play a central role in cellmediated immunity because of their involvement in the initiation of responses as antigen-presenting cells, there are very few reports about the association of macrophages with autoimmune diseases. However, the presence of suppressor macrophages has been described in the patients with rheumatoid arthritis [28] and systemic lupus erythematosus [29]. It is currently uncertain whether suppressor macrophages induce various autoimmune diseases or if these cells appear as a result of disease. Even in the present study, it is not clear how the low responsiveness of NOD spleen cells to Con A caused by suppressor macrophages contributes to the pathogenesis of Type 1 diabetes. Generally, most of the T cells activated by Con A seem to be suppressor $T$ cells. Recently, we have examined the changes of Lyt2- and L3T4-positive $T$ cells in spleen cells from NOD and BALB/c mice before and after culture with Con A by flow cytometry. After stimulation with Con $\mathrm{A}, \mathrm{BALB} / \mathrm{c}$ mice developed a higher percentage of Lyt $2{ }^{+}$T cells, whereas NOD mice did not. On the other hand, the percentage of $\mathrm{L}_{3} 4^{+}$cells among the T cells decreased in both strains of mice after culturing with Con A. These results suggest that suppressor T cells are preferentially stimulated by Con $\mathrm{A}$ and this stimulation is decreased in the NOD mouse. It is conceivable, therefore, that the depressed suppressor $\mathrm{T}$ cell activation may derange the regulatory $T$ cell circuit, allowing the generation or the activation of specific autoreactive helper $\mathrm{T}$ cells recently reported [30] which may participate in the activation of killer cells against pancreatic islets and the formation of autoantibodies to islet cells. Finally, from the above standpoint, the elucidation of future mechanisms concerning suppressor macrophages could be one of the important subjects in the clarification of the pathogenesis of Type 1 diabetes.

Acknowledgements. This work was supported in part by Grant-in-Aid for Scientific Research 61480251 from the Japanese Ministry of Education, Science, and Culture.

\section{References}

1. Buschard K, Ropke C, Madsbad S (1983) T lymphocyte subsets in patients with newly diagnosed Type 1 (insulin-dependent) diabetes. Diabetologia 25: 247-251

2. Gupta S, Fikring SM, Khanna S, Orti E (1984) Deficiency of suppressor $T$ cell in insulin-dependent diabetes mellitus. Immunol Lett 4: 289-294

3. Jackson RA, Morris MA, Haynes BF, Eisenbarth GS (1982) In- 
creased Ia antigen bearing $\mathrm{T}$ cell in type I diabetes mellitus. $\mathrm{N}$ Engl J Med 306: 785-788

4. Alviggi L, Johnston C, Hoskins PJ, Tee DE, Pyke DA, Leslie RD, Vergani D (1984) Pathogenesis of insulin-dependent diabetes: a role for activated T lymphocytes. Lancet II: 4-6

5. Bottazzo GF, Dean BM, McNally JM, Mackey EH, Swift PGF, Gamble DR (1985) In-situ characterization of autoimmune phenomena and expression of HLA molecules in the pancreas in diabetic insulitis. N Engl J Med 313: 353-360

6. Koevary S, Rossini AA, Stoller W, Chick WL, Wikkiam RM (1983) Passive transfer of diabetes in the $\mathrm{BB} / \mathrm{W}$ rat. Science 220: 727-728

7. Like AA, Kislanskis E, Williams RM, Rossini AA (1982) Neonatal thymectomy prevents spontaneous diabetes in the $\mathrm{BB} / \mathrm{W}$ rat. Science 216: 644-646

8. Laupacis A, Stiller CR, Gardell C, Keown P, Dupre J, Wallace AC, Thibert P (1983) Cyclosporin prevents diabetes in BB Wistar rats. Lancet $\mathrm{I}$ : $10-12$

9. Rossini AA, Faustman D, Woda BA, Like AA, Szymanski I, Mordes JP (1984) Lymphocyte transfusions prevent diabetes in the Bio-Breeding/Worchester rat. J Clin Invest 74: 39-46

10. Ogawa M, Maruyama T, Hasegawa T, Kanaya F, Tochino Y, Uda $H(1985)$ The inhibitory effect of neonatal thymectomy on the incidence of insulitis in non-obese diabetic (NOD) mice. Biomed Res 6: 103-105

11. Harada M, Makino S (1986) Suppression of overt diabetes in NOD mice by anti-thymocyte serum or anti-Thyl. 2 antibody. Exp Anim 35: 501-507

12. Makino S, Harada M, Kishimoto Y, Hayashi Y (1986) Absence of insulitis and overt diabetes in athymic nude mice with NOD genetic background. Exp Anim 35: 495-498

13. Fujita T, Yui R, Kusumoto Y, Serizawa Y, Makino S, Tochino Y (1982) Lymphocytic insulitis in a non-obese diabetic (NOD) strain of mice: an immunohistochemical and electron microscope investigation. Biomed Res 3:429-443

14. Koike $\mathrm{T}$, Itoh $\mathrm{Y}$, Ishii $\mathrm{T}$, Ito $\mathrm{I}$, Takabayashi $\mathrm{K}$, Maruyama $\mathrm{N}$, Tomioka H, Yoshida S (1987) Preventive effect of monoclonal anti-L3T4 antibody on developement of diabetes in NOD mice. Diabetes 36: 539-541

15. Zier KS, Leo MM, Spielman RS, Baker L (1984) Decreased synthesis of interleukin-2 (IL-2) in insulin-dependent diabetes mellitus. Diabetes 33: 552-555

16. Kaye WA, Adri MNS, Soeldner JS, Rainowe SL, Kaldany A, Kahn CR, Bistrian B, Srikanta S, Ganda OP, Eisenbarth GS (1986) Acquired defect in interleukin-2 production in patients with type 1 diabetes mellitus. $N$ Engl J Med 315: 920-924

17. Elder ME, Maclaren NK (1983) Identification of profound peripheral $\mathrm{T}$ lymphocyte immunodeficiencies in the spontaneously diabetic BB rat. J Immunol 130: 1723-1731

18. Prud'homme GJ, Fuks A, Colle E, Seemayer TA, Guttmann RD (1984) Immune dysfunction in diabetes-prone BB rats: interleukin 2 production and other mitogen-induced responses are suppressed by activated macrophages. J Exp Med 159: 463-478
19. Woda BA, Padden C (1986) Mitogen responsiveness of lymphocyte from the $\mathrm{BB} / \mathrm{W}$ rat. Diabetes $35: 513-516$

20. Kataoka S, Satoh J, Fujiya H, Toyota T, Suzuki R, Itoh K, Kumagai $\mathrm{K}$ (1983) Immunologic aspects of the nonobese diabetic (NOD) mouse: abnormality of cellular immunity. Diabetes 32 : 247-253

21. Makino S, Kunimoto K, Muraoka Y, Mizushima Y, Katagiri K, Tochino H (1980) Breeding of a non-obese, diabetic strain of mice. Exp Anim 29: 1-13

22. Gillis S, Ferm MM, Ou W, Smith KA (1978) T cell growth factor: parameters of production and quantitative micorassay for activity. J Immunol 120: 2079-2083

23. Ault KA, Springer TA (1981) Cross-reaction of a rat-anti-mouse phagocyte-specific monoclonal antibody (anti-Mac-1) with human monocytes and natural killer cells. J Immunol 126: 359-364

24. Hattori M, Buse JB, Jackson RA, Glimcher L, Dore ME, Minami M, Makino S, Moriwaki K, Kuzuya H, Imura H, Strauss WM, Seidman JG, Eisenbarth GS (1986) The NOD mouse: recessive diabetogenic gene in the major histocompatibility complex. Science 231: 733-735

25. Serreze DV, Leiter EH (1988) Defective activation of T suppressor cell function in nonobese diabetic mice. Potential relation of cytokine deficiencies. J Immunol 140: 3801-3807

26. Metzger Z, Hoffeld JT, Oppenheim JJ (1980) Macropage-mediated suppression: evidence for the participation of both hydrogen peroxide and prostaglandins in suppression of murine lymphocyte proliferation. J Immunol 124: 983-988

27. Unanue ER (1981) The regulatory role of macrophages in antigenic stimulation: symbiotic relationship between lymphocytes and macrophages. Adv Immunol 31: 1-136

28. Zembala M, Lemmel EM (1980) Inhibitor factor(s) of lymphoproliferation produced by synovial fluid mononuclear cells from rheumatoid arthritis patients: the role of monocytes in suppression. J Immunol 125: 1087-1092

29. Markenson JA, Locksin MD, Fuzesi L, Warburg M, Joachim C, Morgan JW (1980) Suprressor monocytes in patients with systemic lupus erythematosus. J Lab Clin Med 95: 40-48

30. Prud'homme GJ, Fuks A, Colle E, Guttmann RD (1984) Isolation of T lymphocyte lines with specificity for islet cell antigens from spontaneously diabetic (insulin-dependent) rats. Diabetes 33: $801-803$

Received: 1 July 1988

and in revised form: 23 November 1988

Dr. Koichi Yokono

Second Department of Internal Medicine

Kobe University School of Medicine

Kobe 650

Japan 